\title{
HORIZONTAL EFFECT OF CONSTITUTIONAL HUMAN RIGHTS IN ISRAEL
}

Anna Rataj

\section{INTRODUCTION}

$\mathrm{n}$ the country with no formal constitution, where basic rights were them were regulated for the first time in two Basic Laws in 1992, it need not be said that the problem of the constitutionalization of horizontal rights is rather a matter of the doctrine and judiciary than that of the positive law. Israel, for this is the country we are talking about, has struggled to reach an agreement on the basic values of the State since its establishment in 1948 . Facing a constant threat to its existence and dealing with ideological conflicts, the state has not yet managed to adopt a fully-fledged constitution that would directly refer to its application in the private sphere.

The Israeli political system is marked by a very strong position of the Supreme Court. Due to an absence of action on the side of the Israeli parliament (the Knesset), the Court undertook the difficult task of protecting fundamental rights and freedoms without a proper constitutional framework. Hearing direct petitions against government authorities, it ruled on issues that in western democracies are enshrined in formal constitutions. It was also the Supreme Court who put theory into practice and, by adopting the indirect application model, enabled the constitutional human rights to permeate into the private sphere. 
This chapter begins with a general introduction to the idea of the horizontal application of constitutional human rights. Further, it presents a short outline of the Israeli constitutional history and seeks to find a constitutional regulation of horizontal rights in Israel. Next, it moves to the indirect application model as a proper theoretical framework for Israel, and analyzes the Kestenbaum case, in which this theory was put into practice for the first time by the Israeli Supreme Court. The subsequent sections discuss the application of constitutional rights by Israeli courts in the employer-employee relationship, in contract law and in tort law. The chapter finishes with a short summary of the conclusions.

\section{THE IDEA OF HORIZONTAL APPIICATION OF CONSTITUTIONAL HUMAN RIGHTS}

Traditionally, the constitutional rights of an individual are directed vis-á-vis the state and aimed at limiting governmental power. This approach has been an undisputable assumption for many years, also in Israel. ${ }^{1}$ The vertical application of human rights, however, does not necessarily make the horizontal application impossible. In 1958 , the German Constitutional Court rendered a judgment in the Lüth ${ }^{2}$ case that opened a new era of the question of horizontal application of constitutional human rights. In this case, the Court differentiated between the subjective and objective aspect of constitutional rights. According to the explanation provided, the subjective aspect of a right is the duty imposed on the state in relation towards an individual, whereas the objective aspect makes that right an objective value of the entire legal system. ${ }^{3}$

1 D. Barak-Erez, l. Gilead, "Human Rights in Private Law - The Israeli Case" in J. Fedtke, D. Oliver (eds.), Human Rights and the Private Sphere. A comparative Study, New York 2007, Pp. 252, 253-254.

2 BVerfG, 15.01.1958 - 1 BvR 400/51; BVerfGE 7, 198 (1958).

3 Cit. A. Barak, "Constitutional Rights and Private Law" in G. Sapir, D. Barak-Erez, A. Barak (eds.), Israeli Constitutional Law in the Making, Ox- 
In the 1980 s, the Israeli Supreme Court began changing its attitude towards the notion of the application of constitutional rights in the private sphere. Alongside the Court's newly discovered inclination towards judicial activism, the immediate reason for this new approach was the progressive privatization of the public sector in Israel, which shifted some powers from administrative authorities to private entities. This resulted in the necessity to counterbalance the unequal power between the actors of private law with the protection of human rights. ${ }^{4}$

The adoption of the idea of horizontal application of human rights in private law in Israel is customarily attributed to the Supreme Court Justice and President Aharon Barak, who laid out his theory on indirect application of constitutional human rights in his obiter dictum to the Kestenbaum case ${ }^{5}$ (1992). Thus, the partial enactment of the bill of rights in two Basic Laws in 1992 combined with Barak's theory were the major factors that enabled "the constitutionalization of private law" in Israel. ${ }^{6}$

\section{ON THE WAY TO THE CONSTITUTION}

When Israel was founded in 1948, the Declaration of Independence provided that the country will adopt a written democratic constitution. The elected constituency that later became the First Knesset had not managed to adopt one. Numerous political, social and ideological factors rendered reaching a compromise over the constitution impossible. In 1950, the First Knesset adopted the Harari Resolution, which

ford-Portland 2013, Pp. 379, 388 (Hart Studies in Comparative Public Law, Vol. 2).

4 D. Barak-Erez, I. Gilead, "Human Rights in Private Law...", p. 255.

5 CA 294/91, Jerusalem Community Burial Society v. Kestenbaum, 46 (2) PD 464, 531 (1992). Unofficial translation into English available at <http:// www.utexas.edu/law/academics/centers/transnational/work_new/israeli/case. php?id=1391>, 16 February 2015.

6 Ibid. 
stated that: "The Constitution shall be composed of individual chapters in such a manner that each of them shall constitute a basic law in itself. (...) all chapters together will form the State Constitution."7

Up to 1992, the Knesset had adopted 9 Basic Laws that covered the matter of state institutions, economy, army and Israel lands. ${ }^{8}$ When the Knesset was occupied with introducing the details of the functioning of the state, at the same time, beginning with the Kol Ha'am ${ }^{9}$ decision in 1953, the Israeli Supreme Court was consequently building up an ample case law on basic rights and freedoms of human and citizen. Acting in its capacity as the High Court of Justice, ${ }^{10}$ the Court heard direct petitions from Israeli citizens (and since 1967 also from inhabitants of the occupied territories) who claimed that actions by the government authorities had infringed upon their rights. By granting protection to those unwritten rights, the Supreme Court has developed a body of judge-made law described by some scholars as a "judicial" or "unwritten" bill of rights." This bill included inter alia: freedom of speech and press, ${ }^{12}$ freedom of assem-

7 Harari Resolution, 5 DK [Divrey HaKnesset $=$ Knesset Resolutions] 1743 (June 14, 1950). Original text in Hebrew available at <http://www.huka.gov.il/ wiki/makor/44.pdf>, 16 February 2015.

B Basic Law: The Knesset, SH [Sefer HaHukim = Official Gazette] 244 (1958) 69; Basic Law: The Government, SH 540 (1968) 226; Basic Law: The Government, SH 1396 (1992) 214; Basic Law: The Govemment, SH 1780 (2001) 158; Basic Law: Israel Lands, SH 312 (1960) 56; Basic Law: The President of the State, SH 428 (1964), 118; Basic Law: The State Economy, SH 777 (1975) 206; Basic Law: The Army, SH 806 (1976) 154; Basic Law: Jerusalem, Capital of Israel, SH 980 (1980) 186; Basic Law: Judiciary, SH 1110 (1984) 78; Basic Law: The State Comptroller, SH 1237 (1988) 30.

$9 \mathrm{HCJ} 73 / 53$, Kol Ha'am Company Ltd. v. Minister of Interior, 7 PD [Piskei Din = Court Decisions] 871 (1953).

10 Basic Law: Judiciary grants the Court two capacities: it shall hear appeals against judgments and other decisions of the District Courts (sec. 15 (b)) and, when sitting as a High Court of Justice, it shall hear matters in which it deems necessary to grant relief for the sake of justice (sec. 15 (c)).

$"$ G.E. Carmi, "A constitutional Court in the Absence of a Formal Constitution? On the Ramifications of Appointing the Israeli Supreme Court as the Only Tribunal For Judicial Review", Connecticut Joumal of International Law, Vol. 21, No. 1 (2005), p. 74.

12 HCJ 73/53, Kol Ha'am...

I46 - ANNA RATAJ 
bly, ${ }^{13}$ freedom of association, ${ }^{14}$ freedom of profession, ${ }^{15}$ freedom of movement ${ }^{16}$ and the right to equality. ${ }^{17}$

In 1992, two Basic Laws on human rights were adopted that regulated some of the basic rights included in the judicial bill of rights. ${ }^{18}$ In 1995, in its famous Bank HaMizrahi ${ }^{19}$ decision, the Israeli Supreme Court announced that Israel does have a constitution that comprises of 11 Basic Laws. The Basic Laws of 1992 have enabled the completion of the constitutional process by the presence of limitation clauses that, so Chief Justice Barak, made them superior to the ordinary statutes enacted by the Knesset. ${ }^{20}$ In 2014, the newest Basic Law: Referendum was introduced. ${ }^{21}$

The emergence of a constitution in Israel raised the question of the possibility of its application on the horizontal level.

\section{SEARCHING FOR A CONSTITUTIONAL REgULATION ON HORIZONTAL RIGHTS IN ISRAEL}

The scarce regulation of human rights in Israeli Basic Laws does not mention any type of relations between individuals nor does it contain any provisions on the horizontal application of constitutional rights. The list of protected constitutional rights includes: freedom of occupation, ${ }^{22}$ the right to life, human dignity, property, liberty, freedom

\footnotetext{
$13 \mathrm{HCJ} 148 / 79$. Saar v. Minister of Interior and Police, 34 PD 169 (1979).

14 HCJ FH 16/61, Company Register v. Kardosh, 16 PD 1209 (1962).

is $\mathrm{HCJ} 1 / 49$, Bejarano v. Minister of Police, 2 PD 80 (1949).

$16 \mathrm{HCJ} 111 / 53$, Kaufman v. Minister of Interior, 7 PD 534 (1953).

$17 \mathrm{HCJ} 98 / 69$, Bergman v. Minister of Finance and State Comptroller, 23 (1) PD 693 (1969).

18 Basic Law: Human Dignity and Freedom, SH 1391 (1992) 150; Basic Law: Freedom of Occupation, SH 1454 (1994) 90.

19 CA 6821/93. United Mizrahi Bank v. Migdal Cooperative Village, 49 (4) PD 195 (1995).

20 Ibid., president Barak's opinion.

21 Basic Law: Referendum, SH 2443 (2014) 400.

22 Basic Law: Freedom of Occupation, sec. 2, 3.
} 
of movement to and from Israel and the right to privacy. ${ }^{23}$ The Israeli Supreme Court has broadened the scope of some of these rights (especially human dignity) and started to grant protection to rights not expressly mentioned in the Basic Law. ${ }^{24}$ Therefore, as Barak suggested, the term "constitutional rights" is intended to describe rights expressly or impliedly guaranteed by the Israeli constitution. ${ }^{25}$

In the absence of direct provisions regarding the application of constitutional rights on the horizontal level, a question arises: do Basic Laws contain any option that would enable those rights to be applicable to the relationships between individuals in some other way?

Both Basic Laws of 1992 contain a provision that refers to the basic values of the State. "Fundamental human rights in Israel are founded upon recognition of the value of the human being, the sanctity of human life, and the principle that all persons are free; these rights shall be upheld in the spirit of the principles set forth in the Declaration of the Establishment of the State of Israel." ${ }^{26}$ Both Basic Laws also set the purpose of their regulation. Section 1a of Basic Law: Human Dignity and Liberty reads as follows: "The purpose of this Basic Law is to protect human dignity and liberty, in order to establish in a Basic Law the values of the State of Israel as a Jewish and democratic state."27 Respectively, Basic Law: Freedom of Occupation provides for: "The purpose of this Basic Law if to protect freedom of occupation, in order to establish in a Basic Law the values of the State of Israel as a Jewish and democratic state." ${ }^{28}$

The revocation to the spirit of the principles of the Declaration of Independence and setting a purpose in the values of the State of

\footnotetext{
23 Basic Law: Human Dignity and Freedom, sec. 2-7.

24 S. Navot, The Constitution of Israel. A Contextual Analysis, Oxford-Portland 2014, pp. 193, 200 (Constitutional Systems of the World).

25 A. Barak, "Constitutional Rights and Private Law", p. 379.

26 Basic Law: Human Dignity and Freedom, sec. 1; Basic Law: Freedom of Occupation, sec. 1.

27 Basic Law: Human Dignity and Freedom, sec. 1a. This section was introduced in 1994 as amended by Basic Law: Freedom of Occupation.

28 Basic Law: Freedom of Occupation, sec. 2.
} 
Israel as a Jewish and democratic state show that Basic Laws are intended to shape the character of the Israeli society. ${ }^{29}$

On the other hand, both Basic Laws contain an application clause which expressly binds governmental authorities. Section 11 of Basic Law: Human Dignity and Freedom (1992) provides for as follows: "All governmental authorities are bound to respect the rights under this Basic Law." ${ }^{30}$ Similarly, section 5 of Basic Law: Freedom of Occupation (1994) reads: "All governmental authorities are bound to respect the freedom of occupation of all Israel nationals and residents." ${ }^{\prime 1}$ This regulation bears a resemblance to the US Constitution, for instance its First Amendment: "Congress shall make no law respecting an establishment of religion, or prohibiting the free exercise thereof; or abridging the freedom of speech, or of the press; or the right of the people peaceably to assemble, and to petition the government for a redress of grievances." ${ }^{32}$

Most provisions of the US Constitution have only a vertical effect. They are directed vis-á-vis the State and local government and do not apply to actions between individuals. ${ }^{33}$ Barak argued that the aforementioned provisions of the Basic Laws should not be construed as ones that narrow the scope of application of those rights. The fact that they expressly bind the state authorities does not exclude their application to the relations between private individuals. They should rather be construed as emphasizing the duty of public authorities to abide by the constitutional human rights guaranteed by the Basic Laws rather than excluding any other possibility of their application. ${ }^{34}$

29 M. Tamir, "Human Rights in Private Law: Hybridization of the Balancing Test" in G. Sapir, D. Barak-Erez, A. Barak (eds.), Israeli Constitutional Law..., pp. 401, 403.

30 Basic Law: Human Dignity and Freedom, sec. 11.

31 Basic Law: Freedom of Occupation, sec. 5.

32 United States Constitution, First Amendment (1791).

33 M. Cohen-Eliya, "The Israeli Case of a Transformative Constitutionalism" in G. Sapir, D. Barak-Erez, A. Barak (eds.), Israeli Constitutional Law..., pp. 173, 183 .

34 A. Barak, "Constitutional Rights and Private Law", p. 397. 
5. THE INDIRECT APPLICATION MODEL AS A THEORETICAL FRAMEWORK FOR ISRAEL

Following Barak's conclusion, a question arises as to possible models of application - whether these rights should apply directly to relationships between individuals or rather indirectly by influencing the interpretation of general clauses in private law. ${ }^{35}$ When laying out his theory of horizontal application of constitutional human rights, Barak presented four possible models of application: (1) the direct application model, (2) the non-application model, (3) the application to the judiciary model, (4) the indirect application model. ${ }^{36}$ After elaborating on these models, he decided that the indirect application model is the most suitable one for the Israeli constitutional history. ${ }^{37}$

As already mentioned, the indirect application model was developed by the German Constitutional Court starting from the Lüth case. ${ }^{38}$ The model provides for direct application of an individual's constitutional rights towards the state and indirect application towards another individual. An individual does have constitutional rights towards the state but does not have such rights towards another individual. Rights between individuals are not at the constitutional but at the sub-constitutional level (statute or common law). ${ }^{39}$ Therefore, the constitutional rights of an individual towards another individual apply only indirectly through interpretation of provisions of private law or completion of the lacunae within it in accordance with objective constitutional principles. ${ }^{40}$ Private law has already developed the relevant tools for the application of this model which are the general principles of good faith, public policy and reasonableness. Thus, constitutional human rights serve as a source of inspiration for the interpretation of these general principles and affect the balanc-

\footnotetext{
3s D. Barak-Erez, I. Gilead, "Human Rights in Private Law...", p. 256.

36 A. Barak, "Constitutional Rights and Private Law", p. 380.

37 Ibid., p. 397.

38 BVerfG, 15.01.1958 - 1 BvR 400/51; BVerfGE 7, 198 (1958).

39 A. Barak, "Constitutional Rights and Private Law", p. 385.

40 Ibid., pp. 386-387.
} 
ing between rights involved in relationships between individuals. ${ }^{41}$ Barak also expressed his belief that the indirect application model is the most appropriate for accomplishing the goals of human rights, which are respect for equality, dignity and autonomy. ${ }^{42}$

Barak's concept of the indirect application model was later refined towards the strengthened indirect application model. Whereas the direct application model creates a type of "constitutional private law" to provide relief for infringement of constitutional rights, the strengthened model takes into account the existing private law as the appropriate system for providing such a relief. ${ }^{43}$

The question of the horizontal application of constitutional rights should, however, according to Barak, be left open to the decision of the courts. ${ }^{44}$ When dealing with the application of constitutional principles in private law, courts have to establish a balance test to weigh the constitutional values according to the circumstances of the case at hand. ${ }^{45}$ This interpretation opened the gates to adopt the indirect application model in Israeli judicial practice.

\section{THE INDIRECT APPLICATION MODEL AT WORK:}

THE KESTENBAUM CASE

A tuming point in the horizontal application of constitutional rights in Israel was the case Jerusalem Community Burial Society v. Kestenbaum ${ }^{46}(1992)$ decided by the Israeli Supreme Court. The Court rendered the judgment on April 30, 1992, shortly after the enactment of the new Basic Laws dealing with human rights, but the litigation

4 A. Barak, "Constitutional Human Rights and Private Law" in D. Fried. mann, D. Barak-Erez (eds.), Human Rights in Private Law, Oxford-Portland 2001, pp. 13, 14 .
42 Ibid., p. 14 .
43 Ibid., p. 30.
4 I dem, "Constitutional Rights and Private Law", pp. 379, 397.
45 M. Tamir, "Human Rights in Private Law...", p. 417.
46 CA 294/91, Jerusalem Community..., supra note 5. 
had started before they were enacted. The case considered a clash between the contractual freedom of the Jewish Burial Society and the defendant's human dignity. The central question was the relevance of human dignity as a ground for the invalidation of a private contract under the public policy principle. ${ }^{47}$

The facts of the case indicate that the Jewish Burial Society signed a standard contract with Mr. Lionel Kestenbaum, a husband of the deceased, which incorporated the society's regulations. One of them allowed only for Hebrew letters and Hebrew calendar dates to be inscribed on a tombstone. On that ground, the society denied the husband's request who later wished to add Latin letters and Gregorian calendar dates on the tombstone. The husband filed a petition to the Jerusalem District Court in request for a declaratory judgment to grant him rights to engrave Latin letters and Gregorian calendar dates on the grave. During the proceedings, a question arose whether the denial constituted an infringement of human dignity as a constitutional right. The District Court answered this question in affirmative and nullified the provision. The Jewish Burial Society submitted an appeal to the Supreme Court. ${ }^{48}$

Justice Barak, who delivered the opinion to this decision, found the contractual provision void and based this finding on three alternative grounds.

(1) The provision allowing exclusively Hebrew letters on the tombstone was a depriving condition according to the Standard Contracts Law (1982). The Law determines that a court is authorized to annul or vary a condition of a standard contract that "involves an undue disadvantage to customers or an unfair advantage to the supplier, likely to lead to a deprivation of customers." ${ }^{49}$ Barak agreed with the District Court's opinion and after deeply elaborating on this matter he reached the conclusion that the condition requiring the exclusive use of Hebrew characters is "unduly disadvantageous." ${ }^{50}$

47 D. Barak-Erez, I. Gilead, "Human Rights in Private Law...", p. 256.

48 Kestenbaum, Editor's synopsis, facts of the case.

49 Standard Contracts Law (1982), sec. 3 and 19, cit.: Kestenbaum, para. 13.

so Kestenbaum, paras. 13-17. 
(2) The Burial Society is a hybrid body and as such, it is subject to obligations imposed by public law. This includes obeying the constitutional right to human dignity. This right has to be understood broadly as embracing also the freedom of conscience, expression, and thought of the deceased, whose desire for an appropriate burial must be respected. The same applies to the deceased's family. ${ }^{51}$

The members of the deceased's family have the right and the freedom to determine that the memory of their loved one be honored in a way that they deem worthy, and that they be granted the possibility to express their feelings towards him in a manner that they deem appropriate. Engraving a tombstone in the language that the deceased and his family spoke is an expression of this. ${ }^{52}$

On the other hand, in this particular situation, the society's freedom of contract was enhanced by its general aim to promote the Hebrew language. As Barak admitted, "The value of the Hebrew language is one of the basic principles of our legal system. ${ }^{n 33}$ This means a head-on clash with the defendant's human dignity which requires establishing a balance between the public value of the Hebrew language and human dignity. In this situation, Barak poses a question:

Is a public body exercising governmental authority, such as the Burial Society, authorized to significantly and severely infringe human dignity (i.e. of the deceased or his relatives) in order to promote the value of the Hebrew language? In my opinion. the answer to this question is in the negative. (...). In this clash between the Hebrew language and human dignity, the latter prevails. ${ }^{54}$

\footnotetext{
si Ibid., para. 6.

52 Ibid.

53 Ibid., para. 12.

54 Ibid., para. 11.
} 
(3) The third ground for nullifying the provision of the contract is the implementation of the indirect application model. Barak expressed his belief that he would have reached the same conclusion, had the Burial Society been an entirely private body. ${ }^{55}$ The provision allowing exclusively Hebrew letters on the tombstone infringed upon the claimant's constitutional right to human dignity through the concept of public policy. The separation between the public and private law shall not be understood as one that does not allow any interactions between them. Therefore, the application of constitutional human rights should not be limited exclusively to public law. ${ }^{56}$ "It should seem clear and obvious that the basic principles of the legal system in general, and basic human rights in particular, are not limited to public law. (...) Indeed, the basic principles are basic to the entire system, and not to the public law alone." ${ }^{157}$ Constitutional human rights apply also in private law. They are not intended to protect only from the state, but impose such a duty on individuals as well. Every individual is obliged to respect these rights in relations with another individuals. This obligation, however, has a different scope than obligation imposed on the state. ${ }^{58}$

Obviously, the government's obligations are stricter, and the protection of human rights from violation by government is more extensive. Indeed, the obligation of an individual to respect his neighbor's rights stems from the same source as that of the government's obligation - the basic social concepts and the basic legal principles that the legal system is built upon..$^{59}$

However, constitutional human rights do not apply directly. The principles of the system in general and human rights in particular

\footnotetext{
55 Ibid., para. 18.

s6 Ibid., para. 20.

57 Ibid.

58 Ibid., para. 22.

59 Ibid.
} 
flow to private law and they are transferred to interactions between individuals through the tools of private law doctrines. ${ }^{60}$

By applying the indirect application model Barak came to the conclusion that the claimant's right to human dignity permeated to contract law through the public policy concept. According to this concept, an appropriate balance has to be found between the freedom of contract and human dignity. In this particular case, the constitutional right to human dignity outweighed the freedom of contract. ${ }^{61}$ For these reasons, the condition incorporated to the contract was contrary to the public policy and therefore void. The appeal of the Jewish Burial Society was to be dismissed. ${ }^{62}$ During the hearing at the Supreme Court, the society agreed to the engraving of the dates of birth and death in numerals, but only on the back of the tombstone. ${ }^{63}$

Kestenbaum is a breakthrough in implementing the indirect application model. The case marks the recognition of the impact of human rights on private law in Israel. ${ }^{64}$

\section{APPLICATION OF CONSTITUTIONAL HUMAN RIGHTS IN THE EMPLOYER-EMPLOYEE RELATIONSHIP}

Long before developing the horizontal rights concept in Israel, the main basis for examining claims between individuals was the public policy clause. The case Cables and Electric Threads Company v. Kristianpoler ${ }^{65}$ (1974) dealt with the non-compete agreement. The Supreme Court established that restrictions put on the former employee in such an agreement must comply with two conditions: (1) necessity to protect the legitimate interest of the employer and

\footnotetext{
60 A. Barak, “Constitutional Rights and Private Law”, p. 398.

61 Kestenbaum, para. 27.

62 Ibid., para. 30.

(3) Ibid., Editor's synopsis, facts of the case.

64 M. Tamir, "Human Rights in Private Law...", p. 406.

os CA 312/74, Cables and Electric Threads Company v. Kristianpoler, 29 (1) PD 316 (1974).
} 
(2) compatibility with the public interest. ${ }^{66}$ The concept of the public policy was not defined by law and was subject to courts' interpretation. ${ }^{67}$ According to Barak's definition, public policy means "the main values, principles and interests that a given society wish to maintain in a given time." ${ }^{\text {"8 }}$

As a result of the adoption of the indirect application model in Israel, constitutional rights also influenced also the employer-employee relationship. The basic right of freedom of occupation changed the character of the public policy concept. ${ }^{69}$ In Kestenbaum, Barak mentioned that "not only the government is obliged to respect the human right of freedom of occupation, but employers, too, must respect the freedom of occupation of their employees." ${ }^{\text {"70 }}$

The new approach can be seen in the AES System Inc v. Saar case $^{71}(2000)$. Similarly as before, the Court found a non-compete agreement void as it contradicted the public policy, but as a result of the impact of the basic right of freedom of occupation, the public policy changed its character. The requirements set by the Court for such a contradiction were less strict than before because the rights of the employee were strengthened by the constitutionally protected freedom of occupation. This case set a new threshold for non-compete agreements: from now on, the options to restrict employees' rights after termination of work were much more limited. ${ }^{22}$

\footnotetext{
66 Kristianpoler, cit.: M. Tamir, 'Human Rights in Private Law...', p. 405.

67 M. Tamir, "Human Rights in Private Law...", p. 405.

68 A. Barak, The Judge in a Democracy, Haifa 2004, p. 259, cit.: M. Tamir, "Human Rights in Private Law...", p. 405.

69 M. Tamir, "Human Rights in Private Law...", p. 405.

70 Kestenbaum, para. 22.

"CA 6601/96, AES System Inc v. Saar, 54 (3) PD 850,860 (2000).

72 AES System Inc v. Saar, cit.: M. Tamir, "Human Rights in Private Law", p. 405 .
} 
8. APPLICATION OF CONSTITUTIONAL HUMAN RIGHTS IN CONTRACT LAW

Prior to the enactment of the partial bill of rights in 1992, it was the Supreme Court who ruled on granting the protection to human rights, building up the judicial bill of rights. In case a private contract infringed upon those rights, the Court would use the principle of public policy to invalidate them. ${ }^{73}$ When such a right was infringed in the precontractual stage, the Court would use the good faith principle. ${ }^{74}$

The first time the Court dealt with the possibility of application of the right to equality in the precontractual phase was in Beit Yules v. Raviv ${ }^{75}(1982)$. In this case the question was raised whether the duty to act in good faith obliges a private tender to equal treatment of the bidders. The majority followed the traditional concept of contractual autonomy and ruled that the principle of good faith does not require equal treatment and does not prohibit discrimination, regardless of circumstances. ${ }^{76}$ The minority believed that the duty of equal treatment was implied by the principle of good faith which applies also to the precontractual stage." Although the majority opinion set a precedent, the minority opinion was of a great importance for the future developments of horizontal application of human rights in private law in Israel. It was delivered by two most prominent Justices of the Supreme Court - Meir Shamgar (the President) and Aharon Barak (his successor in the office). Their argumentation gave hope that in the case of a forbidden form of group discrimination, the Court may reach a different result. ${ }^{78}$

\footnotetext{
73 D. Barak-Erez, I. Gilead, "Human Rights in Private Law...", p. 254.

74 Ibid., p. 261.

75 HCJ FH 22/82, Beit Yules v. Raviv (1982), 43 (1) PD 441.

76 Beit Yules v. Raviv, cit.: A. Barak, "Constitutional Human Rights and Private Law", p. 40.

$\pi$ Beit Yules v. Raviv, cit.: D. Barak-Erez, I. Gilead, "Human Rights in Private Law...", p. 261.

78 D. Barak-Erez, I. Gilead, "Human Rights in Private Law...", p. 262.
} 
Since 1992, according to Barak, the dictum of Beit Yules is not relevant anymore, as equality is now protected by the human dignity clause of the Basic Law: Human Dignity and Freedom. ${ }^{79}$ For those reasons, it must find expression in private law. ${ }^{80}$ In the following cases, the lower courts in Israel have ruled that equality can be used in the precontractual stage as a tool to enforce the closing of a contract when a party refused to enter it for discriminatory reasons. ${ }^{81}$ These decisions show the Israeli courts' openness to apply constitutional human rights in private law. ${ }^{82}$

In Na'amne v. Kibbutz Kalia ${ }^{83}(1996)$, the Jerusalem Magistrate Court dealt with racially-based discrimination against an Israeli-Arab family who was denied entry to a private water resort. The court ruled in favor of the plaintiff and awarded a modest compensation of 10,000 NIS (ca. 2,600 USD). The court provided two bases for the defendant's liability - a tortious and a precontractual one. In terms of breach of precontractual liability, the Court based its ruling on the finding that media advertisements to visit the park constituted a good faith offer as they were directed at the general public. Denying entry stood for a cancellation of the offer at the last minute and violated the contractual obligation of good faith and fair dealings. ${ }^{84}$

Precontractual liability was also the subject of the decision in Shamsiyan v. Rosemary Garden Rest ${ }^{85}$ (1999). The case dealt with a situation in which a disabled woman was denied entry to a bar. Tel

\footnotetext{
7) Basic Law: Human Dignity and Freedom, sec. 2.

so A. Barak, "Constitutional Human Rights and Private Law", p. 40.

81 D. Barak-Erez, I. Gilead, "Human Rights in Private Law...", p. 261.

82 Ibid., p. 262.

B3 CC (Jm) 11258/93, Na'amne v. Kibbutz Kalia, ruled on September 1, 1996 (unpublished), Nevo Legal Database (by subscription).

${ }_{84}$ Na'amne v. Kibbutz Kalia, cit.: ACRI - The Association for Civil Rights in Israel, Comments on the Combined Initial and First Periodic Reports Concerning the Implementation of The International Covenant on Civil and Political Rights (ICCPR), submitted to the United Nations Human Rights Committee, July 1998 . p. 134.

85 CC (TA) 15/97, Shamsiyan v Rosemary Garden Rest, ruled on 12 January 1999 (unpublished), Nevo Legal Database (by subscription).
} 
Aviv Magistrate Court ruled that this case involved intentional discrimination against a disabled person which constituted a breach of good faith. ${ }^{86}$ Another discrimination case was decided by the Haifa Magistrate Court. In Association for the Protection of the Rights of Individuals v. Matzkin ${ }^{87}(1996)$ the Court ruled that an individual cannot be required to disclose his or her sexual orientation when looking for an apartment to rent. ${ }^{88}$

Those cases were deeply influenced by the notion of the application of constitutional rights on the horizontal level and they show that the enactment of the Basic Law: Human Dignity and Freedom had an impact on private law. ${ }^{89}$

\section{APPLiCATION OF CONSTITUTIONAL HUMAN RIGHTS IN TORT LAW}

The application of constitutional rights is even more relevant in tort law than in contract law. Tort law is equipped with appropriate tools for this purpose which are the general framework of breach of statutory duty as well as the concepts of carelessness and duty of care in negligence. ${ }^{90}$ In Israel, the general regulation of tort law was introduced with the Civil Wrong Ordinance which provides for a definition of a damage. This definition is broad enough to include different harms caused by an infringement of constitutional human rights. A number of rights that later became a part of the Basic Laws of 1992 were named expressly in different statutory provisions. ${ }^{91}$ These in.

${ }_{86}$ Shamsiyan v Rosemary Garden Rest, cit.: M. Cohen-Eliya, "The Israeli Case...", p. 184.

87 CC (Ha) $4583 / 96$. Association for the Protection of the Rights of Individuals v. Matzkin, ruled on 23 April 1996 (unpublished), Nevo Legal Database (by subscription).

${ }_{88}$ Association for the Protection of the Rights of Individuals v. Matzkin, cit.: M. Cohen-Eliya, "The Israeli Case...", p. 184.

${ }_{89}$ M. Cohen-Eliya, "The Israeli Case...", p. 183.

9 D. Barak-Erez, I. Gilead,"Human Rights in Private Law...", p. 263.

91 Ibid., p. 254. 
clude bodily integrity (protected by general and specific torts within the concepts of negligence, breach of statutory duty and strict liability), dignity (protected i.a. by defamation law), privacy (protected by law on the protection of privacy) and property (protected by general and specific torts such as trespassing, conversion and passing off), to name a few. ${ }^{92}$

The Israeli Supreme Court has rejected the idea of adopting the direct application model in tort law. The direct application of new $\mathrm{Ba}$ sic Laws would enable the plaintiff to sue on both counts: a traditional tort claim and a constitutional claim for infringement of the protected constitutional right (for example, defamation and violation of the right to dignity). It was feared that the adoption of this model would lead to the creation of a "constitutional law of torts" which would exist alongside the statutory tort law. Besides that, constitutional rights are not detailed enough and do not specify elements required to establish tortious liability. ${ }^{93}$ The Supreme Court has rejected the direct application model in the Da'aka v. Carmel Hospital ${ }^{94}$ (1999) case. Instead of applying the Basic Law: Human Dignity and Liberty directly, it imposed liability on the basis of the tort of negligence, inspired by the value of autonomy protected in this Basic Law and thus applying it indirectly. ${ }^{95}$

In the previously mentioned Na'amne case, the Court provided remedy on both contractual and tortious basis for liability. As far as the tortious basis for liability is concerned, the ruling was an indirect application of constitutional rights. The court ruled that the denial constituted a breach of statutory duty because it violated the obligation of a private institution to respect the right to human dignity, which includes the right not to be humiliated on the basis of national origin. ${ }^{9}$

\footnotetext{
92 Ibid., and further references.

93 Ibid., p. 264.

94 CA 2781/93, Da'aka v. Carmel Hospital 53(4) PD 526 (1999).

95 Da'aka v. Carmel Hospital, cit.: D. Barak-Erez, I. Gilead, "Human Rights in Private Law...", p. 266.

96 ACRI, Comments on the Combined..., p. 134.
} 
The adoption of the indirect application model of the new Basic Laws has strengthened the protection of rights provided by tort law.

\section{CONCLUSION}

In this chapter an attempt was made to present briefly the question of horizontal application of human rights in Israel. In Israeli constitution, there are no provisions relating to this matter. This concept was developed in the scholarship and confirmed by case law of the Israeli courts. Barak's theory of the indirect application model was based on the German Constitutional Court ruling in the Lüth case. As a matter of fact, Israeli doctrine and judiciary follows the German Drittwirkung (impact on third parties) model. ${ }^{97}$ This model has been recognized in all fields of private law in Israel. ${ }^{98}$

In most countries, some of the relationships between private actors are addressed explicitly in the constitution and the analysis concentrates on the question whether they do apply in real life and whether the courts enforce their application. In Israel, the situation is the exact opposite. At the beginning, there was no constitution, and when it finally emerged - and this had not happened until the Israeli Supreme Court so decided - it did not address any relationships between individuals. But the fact that something was not inscribed in laws does not necessarily imply that something does not exist. The creativity of the Israeli judges, and especially that of the Justices of the Israeli Supreme Court, has rendered it possible to put the President Aharon Barak's concept of the indirect application of constitutional human rights into practice. The courts went even further. The scarcity of constitutional regulation on human rights did not provide protection to a number of rights that are a standard in traditional bills of rights. Is it possible for something that does not exist in positive law to be enforceable? The Supreme Court has answered this

97 M. Cohen-Eliya, "The Israeli Case...", p. 183.

98 A. Barak, "Constitutional Rights and Private Law", p. 398. 
question in the affirmative in many cases when it granted protection to rights not explicitly mentioned in the Basic Laws, by broadening their scope far beyond what is perhaps even thinkable in Western democracies. In this manner, the Israeli Supreme Court has built and still builds up a catalogue of constitutional human rights and then applies them in the private sphere, being a good role model to lower Israeli courts. A perfect example of judicial law-making. A true mastery of constitutional argument, indeed.

\section{STRESZCZENIE}

Zagadnienie konstytucjonalizacji stosunków między podmiotami prywatnymi w Izraelu sprowadza się w głównej mierze do doktryny i orzecznictwa. Podejmując próbę znalezienia konstytucyjnej regulacji stosunków horyzontalnych, napotyka się w pierwszej kolejności na przeszkodę w postaci braku konstytucji formalnej, która zawierałaby takie przepisy. Mimo zapowiedzi zawartej w Deklaracji Niepodległości z 1948 r., Izrael do dziś nie ma konstytucji w formie jednego dokumentu o szczególnej randze i supremacji normatywnej. System konstytucyjny Izraela opiera się na 12 ustawach zasadniczych. Kiedy izraelski parlament zajmował się regulowaniem kwestii ustrojowych, Sąd Najwyższy obejmował ochroną poszczególne prawa, które w państwach demokratycznych zakorzenione są w konstytucjach, i w ten sposób tworzył ich niepisany katalog. W 1992 r. Kneset uchwalił dwie ustawy zasadnicze stanowiące wąską regulację niektórych praw podstawowych. O tym, że Izrael ma konstytucję, zadecydował w 1995 r. Sąd Najwyższy, orzekając, że to właśnie ustawy z 1992 r. pozwoliły na dokończenie procesu kształtowania konstytucji.

Regulacja konstytucyjna nie zawiera żadnej wzmianki o stosunkach horyzontalnych. Trudno też doszukać się jakichkolwiek wskazówek między słowami. Dodatkowo, obie ustawy nakładają wyraźne zobowiązanie na wszelkie organy państwowe do poszanowania praw w nich chronionych. Wybitny izraelski konstytucjonalista, były sędzia i prezes Sądu Najwyższego Aharon Barak uznał, że takie sformułowanie nie wyklucza możliwości stosowania konstytucyjnych praw człowieka do stosunków między podmiotami prawa prywatnego. Wzonując się na niemieckiej doktrynie 
po raz pierwszy wyłożonej w orzeczeniu w sprawie Lüth, Barak stworzył model pośredniego stosowania tych praw i dostosował go do izraelskiej rzeczywistości konstytucyjnej. Po raz pierwszy model ten został zastosowany w sprawie Kestenbaum, która dotyczyła konfliktu pomiędzy prawem do godności ludzkiej a swobodą kontraktowania. Sporządzający opinię główną Barak argumentował, że podstawowe zasady systemu prawnego, a w szczególności prawa człowieka, nie są ograniczone do prawa publicznego. Sa one podstawowymi zasadami całego systemu prawnego. W relacjach między podmiotami prywatmymi zasady te nie są stosowane bezpośrednio, lecz przenikają do prawa prywatnego i wpływają na te relacje poprzez doktryny prawa prywatnego, takie jak dobra wiara, rozsądek i klauzula porządku publicznego. Rozstrzygając tę sprawę, Sąd orzekł, że jeśli przepis ustawy narusza godność ludzką, to taki przepis podlega unieważnieniu, ponieważ godność ludzka jest dobrem większym niż swoboda kontraktowania.

Wyrok w sprawie Kestenbaum był punktem zwrotnym w zaadoptowaniu modelu pośredniego stosowania konstytucyjnych praw człowieka w prawie prywatnym. Za ustanowionym w nim precedensie podążyły izraelskie sądy niższych instancji. I tak w relacjach między pracodawcami a pracownikami prawa człowieka znalazły zastosowanie poprzez klauzulę porządku publicznego. Chroniona konstytucyjnie wolność wykonywania zawodu wpłynęła na zawieranie umów o zakazie konkurencji po ustaniu stosunku pracy w ten sposób, że przy sporządzaniu takich umów należy wyważyć pomiędzy potrzebą ochrony uzasadnionego interesu pracodawcy a interesem publicznym w utrzymaniu wolności wykonywania zawodu przez byłego pracownika. Prawa człowieka wywarły również istotny wpływ na odpowiedzialność przedumowną, w szczególności na polu dyskryminacji skutkującej odmową zawarcia umowy. Sąd uznał, że zasada równości stanowi element godności ludzkiej i jako taka podlega ochronie konstytucyjnej. Odmowa zawarcia umowy nosząca znamię dyskryminacji jest naruszeniem zasady równości, która znajduje zastosowanie poprzez koncept dobrej wiary, do jakiej zobowiązane są podmioty zmierzające do zawarcia umowy. Zastosowanie konstytucyjnych praw człowieka na polu odpowiedzialności z tytułu czynów niedozwolonych jest możliwe poprzez koncepcję naruszenia obowiązku ustawowego, obowiązku zachowania należytej staranności i niedbalstwo. Prawa chronione na poziomie ustawowym zostają wzmocnione przez pośrednie stosowanie praw konstytucyjnych. 
Brak regulacji stosunków horyzontalnych w konstytucji nie oznacza, że prawa człowieka nie znajdują zastosowania do relacji między podmiotami indywidualnymi w Izraelu. Poprzez adaptację modelu pośredniego stosowania prawa te przenikają w sferę prawa prywatnego i wzmacniają prawa gwarantowane na poziomie ustawowym. Decydującą rolę w tym procesie odgrywa izraelski Sąd Najwyższy, który poprzez swoje orzecznictwo gwarantował i nadal gwarantuje ochronę praw podstawowych od samego początku istnienia państwa.

\section{BIBLIOG RAPHY}

Barak A., "Constitutional Human Rights and Private Law" in D. Friedmann, D. Barak-Erez (eds.), Human Rights in Private Law, OxfordPortland 2001.

Barak A., "Constitutional Rights and Private Law" in G. Sapir, D. Barak-

Erez, A. BAraK (eds.), Israeli Constitutional Law in the Making, OxfordPortland 2013 (Hart Studies in Comparative Public Law, Vol. 2).

BARAK A., The Judge in a Democracy, Haifa 2004.

Barak-Erez D., Gilead I., "Human Rights in Private Law - The Israeli

Case $^{n}$ in J. Fedtke, D. Oliver (eds.), Human Rights and the Private Sphere. A comparative Study, New York 2007.

CARmi G.E., "A constitutional Court in the Absence of a Formal Constitution? On the Ramifications of Appointing the Israeli Supreme Court as the Only Tribunal For Judicial Reviewn, Connecticut Journal of International Law, Vol. 21, No. 1 (2005).

Сонen-Eliya M., "The Israeli Case of a Transformative Constitutionalism" in G. SAPIR, D. Barak-Erez, A. Barak (eds.), Israeli Constitutional Law in the Making, Oxford-Portland 2013 (Hart Studies in Comparative Public Law, Vol. 2).

Navor S., The Constitution of Israel. A Contextual Analysis, Oxford-Portland 2014 (Constitutional Systems of the World).

TAmir M., "Human Rights in Private Law: Hybridization of the Balancing Test" in G. SAPIR, D. Barak-Erez, A. BaraK (eds.), Israeli Constitutional Law in the Making, Oxford-Portland 2013 (Hart Studies in Comparative Public Law, Vol. 2). 